\title{
THE FIRST SALPAUSSELKÄ AT LOHJA, SOUTHERN FINLAND
}

\author{
GUNNAR GLÜCKERT
}

GLC̈KERT, GUNNAR, 1986: The First Salpausselkä at Lohja, southern Finland. Bull. Geol. Soc. Finland 58, Part 1, 45-55.

Four morphogenic types of the First Salpausselkä can be distinguished in the Lohja area: glaciofluvial marginal deltas, incompletely developed deltas, other ridges and hills, and formations with a rock core. The primary morphology has been considerably deformed by shore action during the stages of the Baltic Ice Lake, the Yoldia phase and the Ancylus Lake of the ancient Baltic.

The Salpausselkä is composed of glaciogenic waterlain sediments, consisting of well-washed and sorted delta beds of sand and gravel, and of poorly sorted till layers. This Salpausselkä till was deposited partly as subaquatic flow till or subglacial meltout till from the debris-loaded ice margin in the proximal part of the formation. The distal and central parts of a typical marginal delta are characterized by undeformed regular flow (delta) structure. The proximal part often contains heterogeneous material, is complicated in structure and has been deformed mainly by glaciotectonic and load deformation structures, such as flow and load casts, faults and folds.

The First Salpausselkä has a complex polygenetic genesis. It was formed in several phases at the ice margin, mainly under subaquatic glaciolacustrine conditions at the same time as the water level of the Baltic was gradually rising from a low level to the highest level of the Baltic Ice Lake, B I. The stratified core and distal strata were deposited first, and then the heterogeneous proximal sediments under conditions associated with a floating and oscillating ice margin before the final retreat of the ice.

The trend of deglaciation within the Salpausselkä belt is closely connected with the genesis of these ice-marginal formations. The general position and formation of the Salpausselkä seem to have been controlled primarily by climatic and topographic factors.

Key words: morphology, delta, deposition, bed, stratified, glaciofluvial structure, Salpausselkä till, waterlain, deformation, glaciotectonic, load structure, genesis, subaquatic, Baltic.

Gunnar Glückert: Department of Quaternary Geology, University of Turku, SF-20500 Turku, Finland.

\section{Introduction}

The most prominent ice-marginal formations in Finland, the Salpausselkä end moraines, have been the subject of geological studies for more than a hundred years. Being composed of glaciofluvial material they have been explained as having been formed at the ice margin (e.g., Wiik 1876, Sederholm 1889, 1910, Ramsay 1891, Leiviskä 1920). The name Salpausselkä was first 


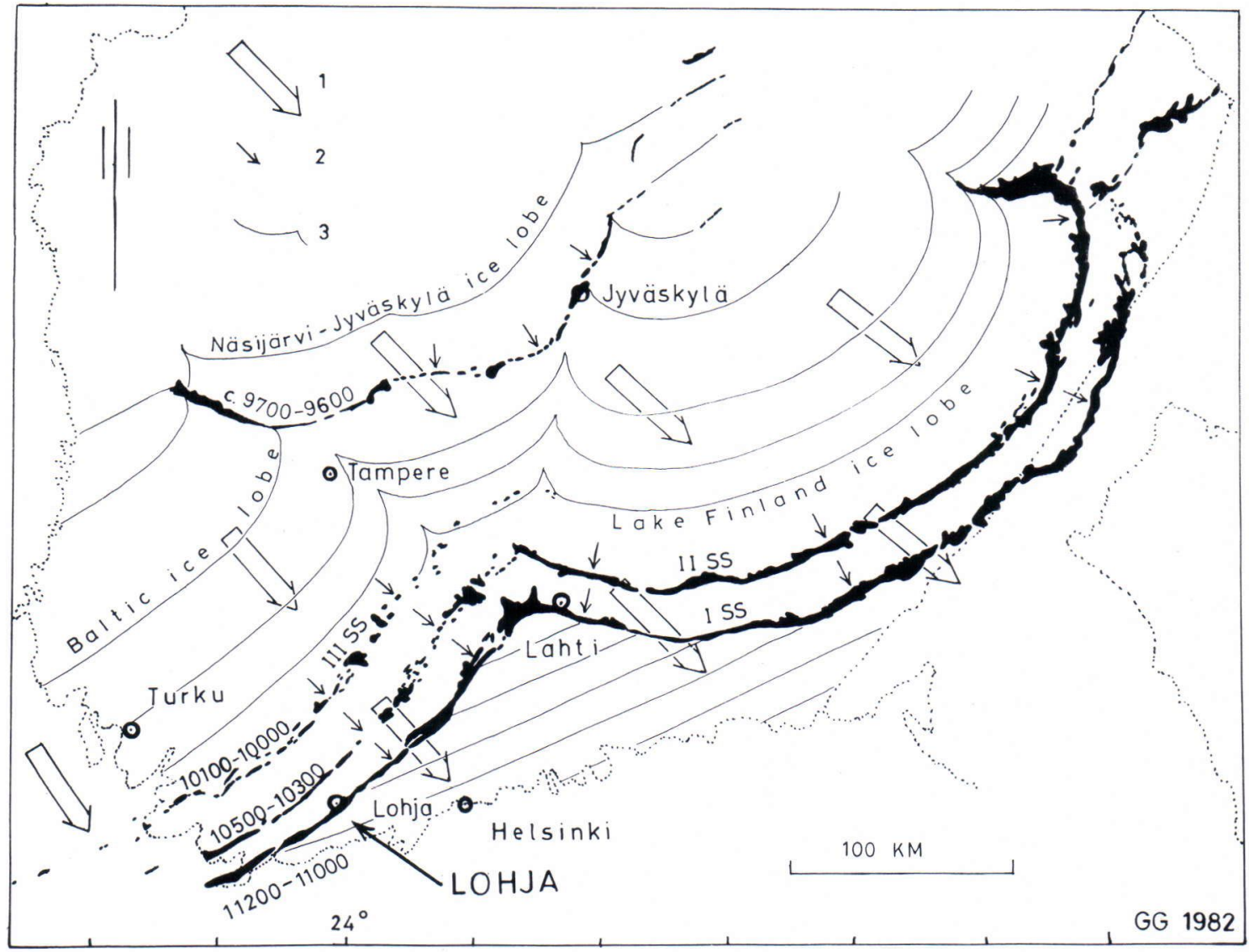

Fig. 1. Main Late Weichselian ice movements (1), the latest ice advances of the Lake Finland, the Baltic and the NäsijärviJyväskylä ice lobes with corresponding end moraines, the First, Second and Third Salpausselkäs (SS) and Central Finland (2), and deglaciation lines older and younger than the SS stages (3).

used in the literature by $\mathrm{Cl}$. W. Gylden in 1857 (Ramsay 1921, p. 9).

The first notable treatise about the Salpausselkä was that published by Leiviskä in 1920 . He divided the ridges and slopes of the Salpausselkä into various morphological types, and described the material, structure and genesis of the end moraine. The structure and genesis of the Salpausselkä in southern Finland has since been described by Leiviskä $(1923,1927,1931)$ and several other scientists, e.g., Ramsay (1922), Metzger (1927), Brenner and Tanner (1930), Sauramo (1931, 1940, 1958), Tanner (1933), Donner (1951, 1952), Hyyppä (1951, 1966), V. Okko
(1957), M. Okko (1962), Virkkala (1963, 1964, 1979), Repo and Tynni (1967, 1969), Aartolahti (1968, 1972), Glückert (1969, 1970, 1975, 1977, 1978, 1981), Fogelberg (1970) and Niemelä (1979).

We have been collecting material about the morphology, structure and genesis of the First Salpausselkä in southern Finland for 20 years. The present paper gives some results of these investigations, with reference to the First Salpausselkä in the Lohja area, about $50 \mathrm{~km}$ west of Helsinki. The shore-level displacement of the Baltic at Lohja is briefly described (Fig. 1). 


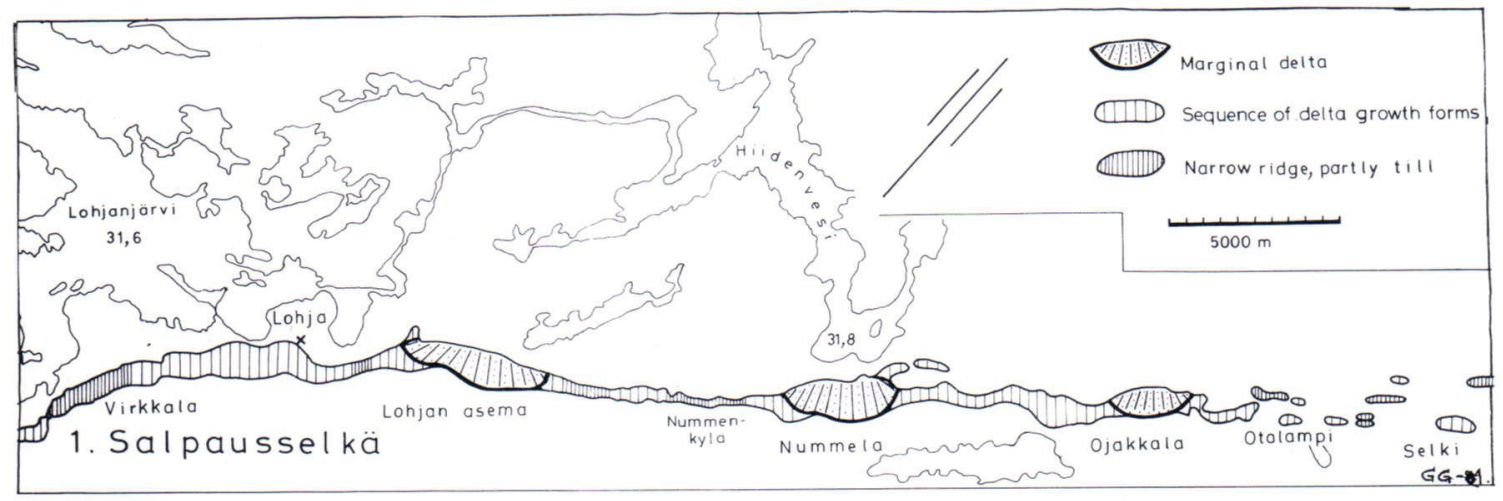

Fig. 2. Most of the Salpausselkä ridges represent marginal deltas or sequences of delta growth forms (see Figs. 3-4) (from Glückert 1981).

\section{Morphogenic types of the First Salpausselkä}

The First Salpausselkä runs as a ridge, 0.5-1 $\mathrm{km}$ broad, through the Lohja area, rising about 30-80 metres above the surrounding cultivated fields and the lake Lohjanjärvi (31.6 $\mathrm{m}$ a.s.l.), and about $90-118 \mathrm{~m}$ above sea level. The formation itself consists mainly of glaciofluvial material, 20-60 m thick, deposited as deltas in the ancient Baltic (Fig. 2).

The morphology of the First Salpausselkä varies considerably in different areas. Leiviskä (1920, pp. 262-292) distinguished three morphological types: narrow ridges, plateau ridges and smooth plateau surfaces.

Four morphogenic types can be distinguished in the Lohja area (Glückert 1975, 1977, 1981) (Figs. 2 and 3):

- glaciofluvial marginal deltas (Fig. 3 A);

- incompletely developed deltas, forming a sequence of glaciofluvial delta growth forms (Figs. 3 B, and 4);

- other ridges and hills, composed of glaciofluvial and partly morainic material (Fig. 3 C); and

- formations with a rock core (Fig. 3 D).

The kame topography with kettle holes typical of most parts of the Salpausselkä formations is lacking in the Lohja area. After the formation

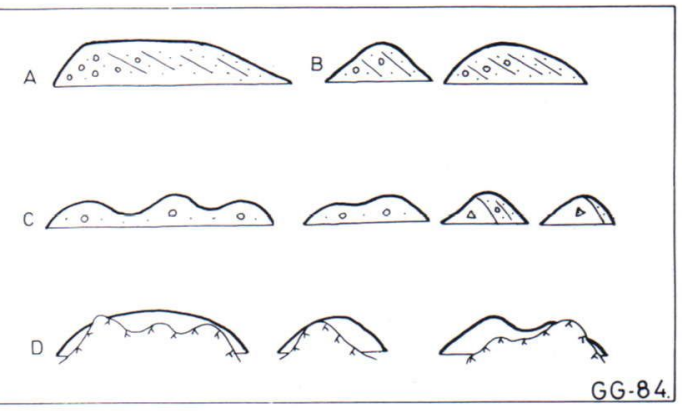

Fig. 3. Morphogenic types of the Salpausselkä formation (see text).

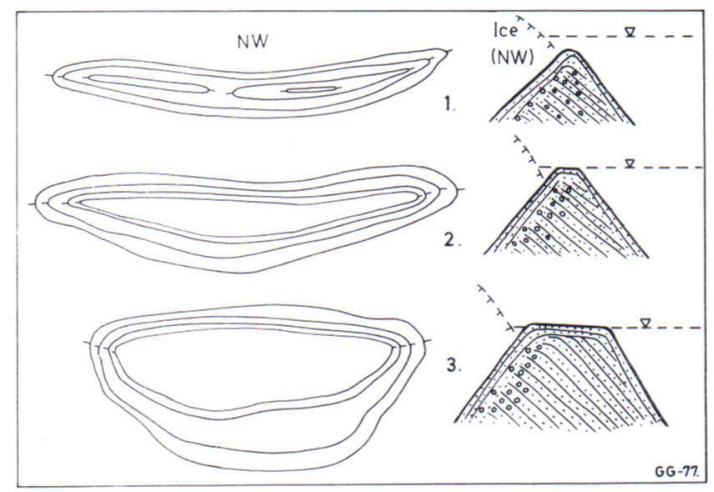

Fig. 4. Sequence of glaciofluvial delta growth forms (from Glückert 1975 and 1981). 

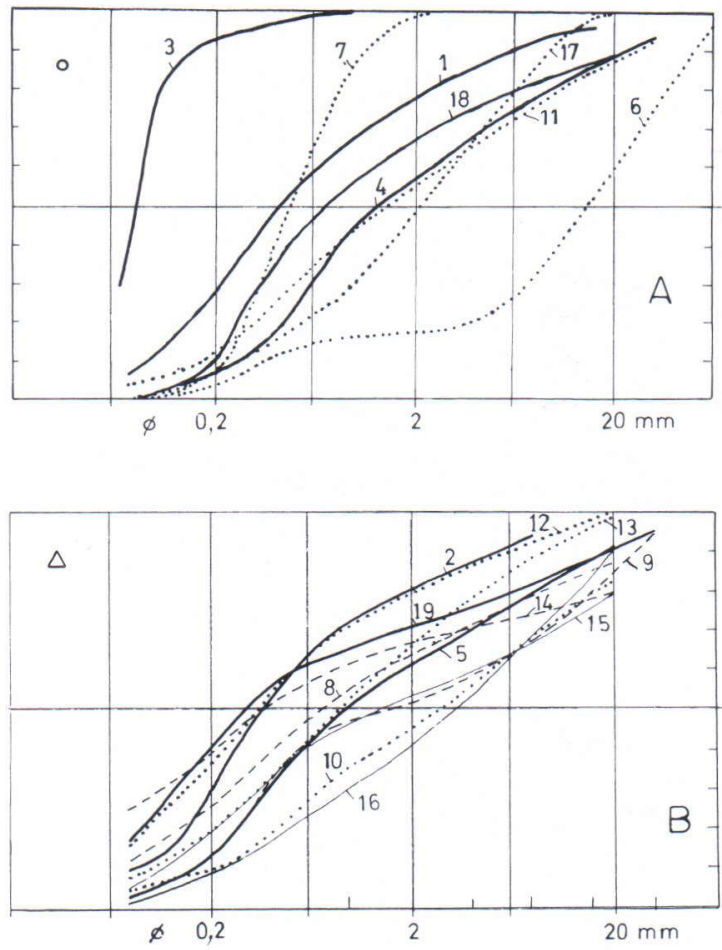

Fig. 5. Grain size composition of stratified drift (A) and Salpausselkä till (B) in the Lohja area (from Glückert 1981).

of the Salpausselkä its general primary morphology was deformed by shore action during the stages of the ancient Baltic. In many areas the original shape of the main ridge has changed considerably, the primary slopes being cut stepwise into cliffs and terraces, which dominate the present morphology of the First Salpausselkä (Glückert 1970, 1975, 1977, 1981) (see Fig. 16).

\section{Material and structure}

The First Salpausselkä consists mainly of a glaciogenic waterlain sediment sequence of sublacustrine origin. The material in general is stratified, well-washed, and sorted, the grain size varying from silt to stones and boulders. The proximal part of the formation is made up of

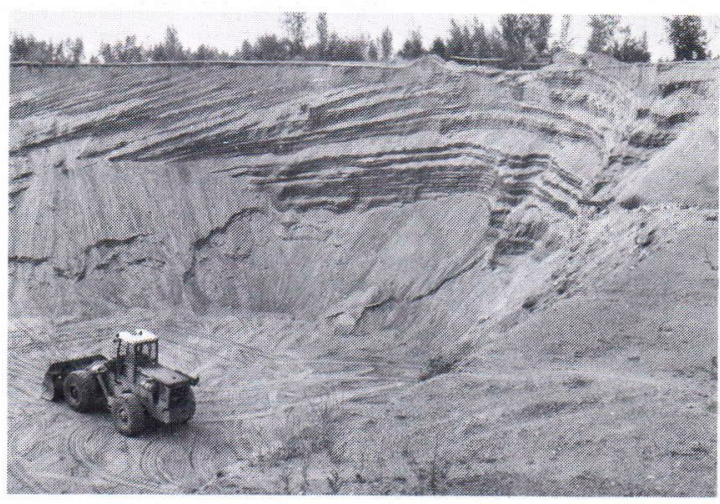

Fig. 6. Typical stratified structure in the distal part of a marginal delta at Röykkä. Photo Glückert 26. 5. 80.

coarser and more heterogeneous drift than is the distal part.

Poorly sorted and washed morainic material is common especially in the proximal part and the narrow ridges of the Salpausselkä. The bulk of this Salpausselkä till can be regarded as subaquatic flow till or subglacial melt-out till. This largely waterlain till is slightly washed and stratified and less compact than basal till usually is in Finland (Figs. 5, 7 and 8).

The round-edged blocks and stones of the till are not oriented in the direction of the ice movement. The Salpausselkä till, rich in silt and sand, appears in sections as beds, $0.2-1 \mathrm{~m}$ thick, containing thin layers or lenses of stratified drift. The subaquatic genesis of the till is confirmed by icedrifted drop stones, some of them $0.5-1 \mathrm{~m}$ in diameter (Glückert 1981, pp. 12-14) (see also Dreimanis 1979, Punkari 1980).

The general structure of the Salpausselkä is characterized by typical delta beds (foreset beds) dipping in a distal direction (Figs. 6 and 8). The central and distal parts exhibit undeformed, regular flow (delta) structure, whereas the proximal part tends to be deformed and much more complex owing to one diversity of conditions - subaquatic and subglacial sedimentation, oscillating and floating ice margins, erosion and accumulation due to meltwater, and load and 


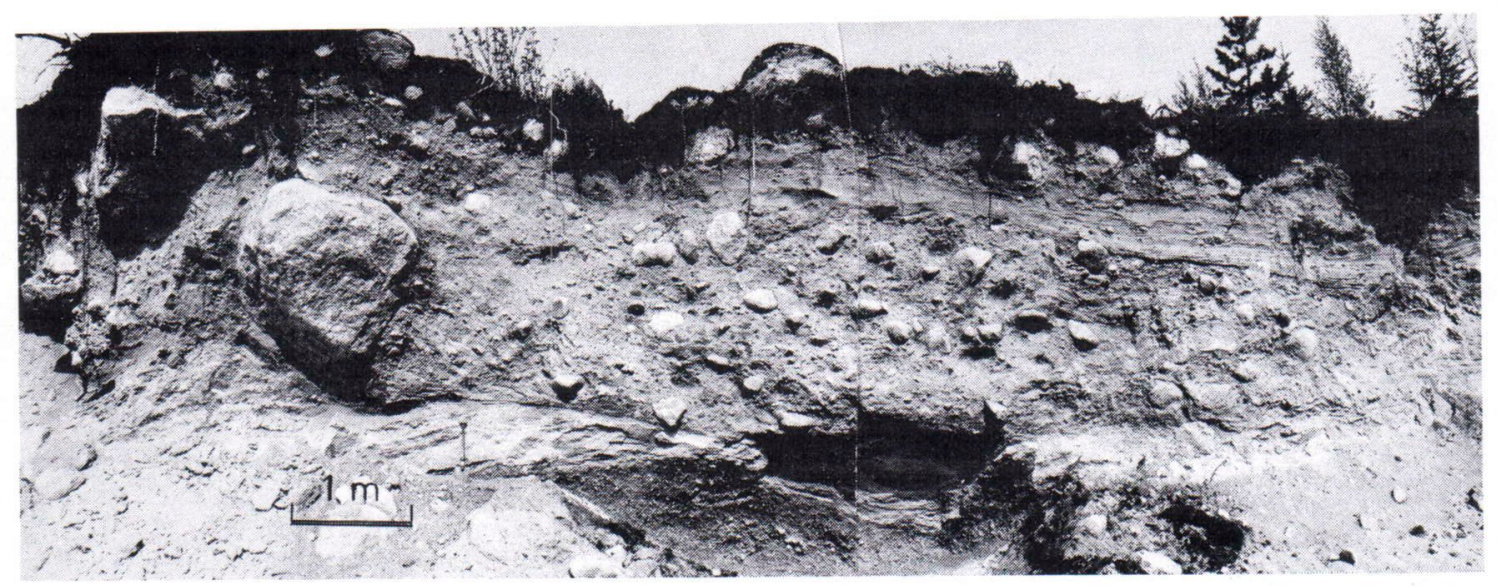

Fig. 7. Subglacial melt-out till, deposited mainly as waterlain till in a narrow ridge at Nummenkylä. Photo 21.5 .72$.

flow phenomena in the material. Discordances, faults, folds, load and flow casts (convolutions, collapse and consolidation structures) are common in both the sorted and unsorted sediments. The waterlain sediment structure in the proximal part of the formation often dips towards the glacier as a result of the last subglacial sedimentation of material from the floating ice margin (Figs. 8-11).

Later, littoral forces deformed the primary glaciofluvial material into a secondary shore bed that covers the whole formation. A clear discordance, often with a layer of stones at the bottom, separates the homogeneous shore bed from the primary glaciofluvial strata (Glückert 1981).

In the Lohja area the First Salpausselkä can be divided structurally into the following undeformed and deformed, primary and secondary types (Glückert 1981):

- undeformed regular flow structures, mainly stratified delta, melt-out and waterlain structures:

- undeformed and deformed till and silt bed structures;

- deformed flow structures, such as erosion accumulation structures (discordances, etc.), and flow and load structures (e.g., convolution folds, collapse, and consolidation structures);
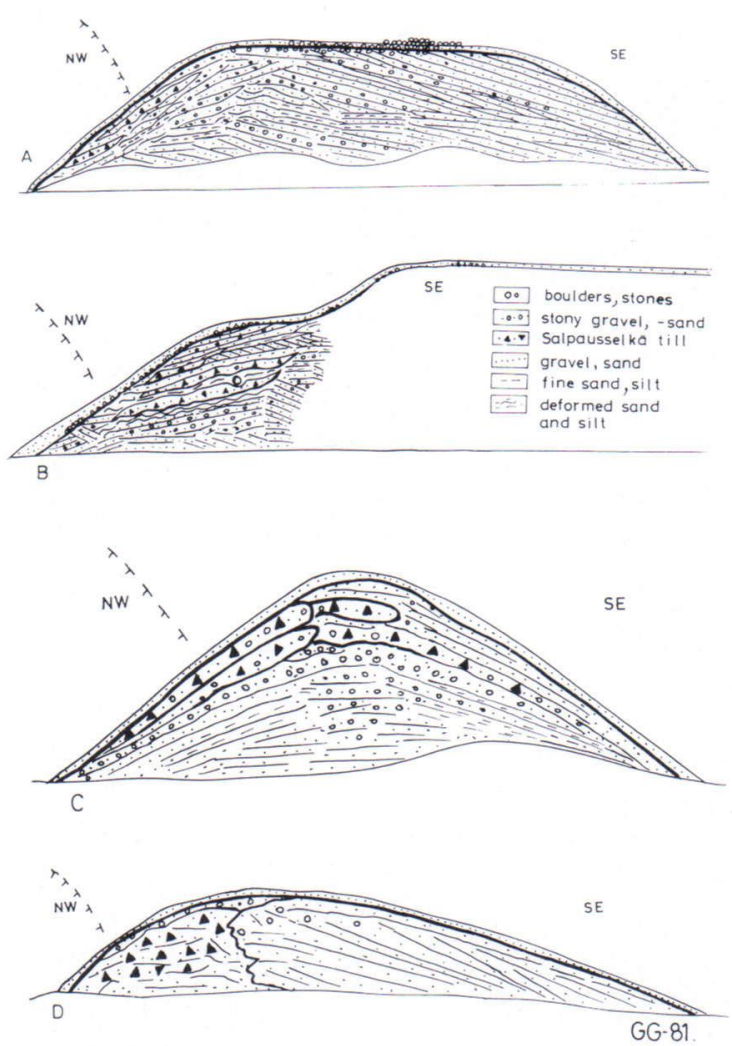

Fig. $8 \mathrm{~A}-\mathrm{D}$. General structure of the marginal delta at Lohja station (A); subaquatic sediment structure in the proximal part of the First Salpausselkä at Lohja station (B); structure of narrow ridges, composed partly of till, at Otalampi (C) and Meltola (D = Fig. 9) (from Glückert 1981). 


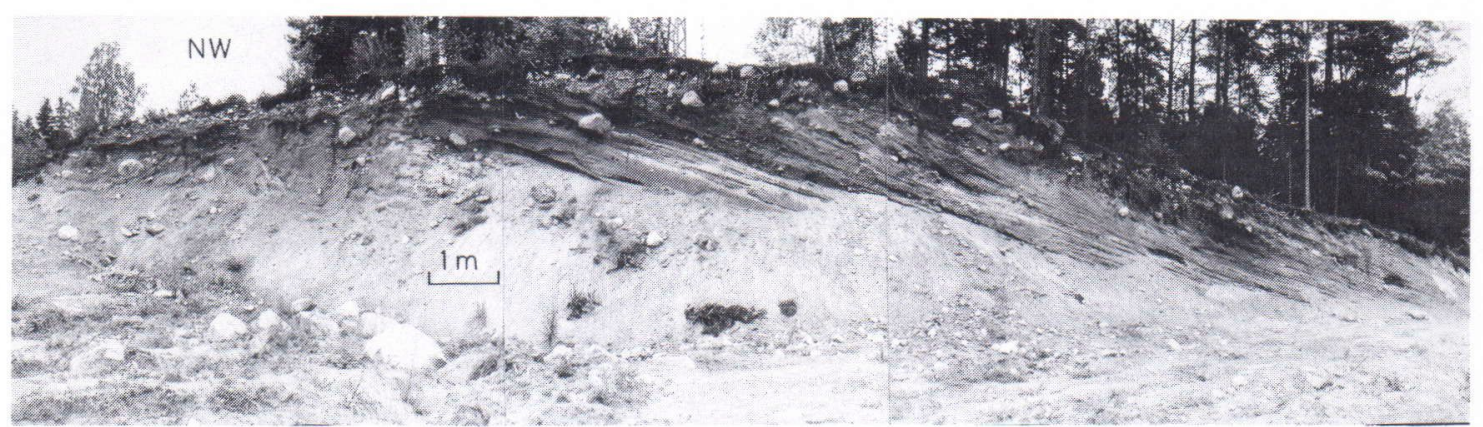

Fig. 9. Structure of a narrow low ridge at Meltola near Karjaa, where the till of the proximal part passes into the sorted delta sediments of the central and distal parts of the formation (= Fig. 8, D). Photo 31. 8. 78.

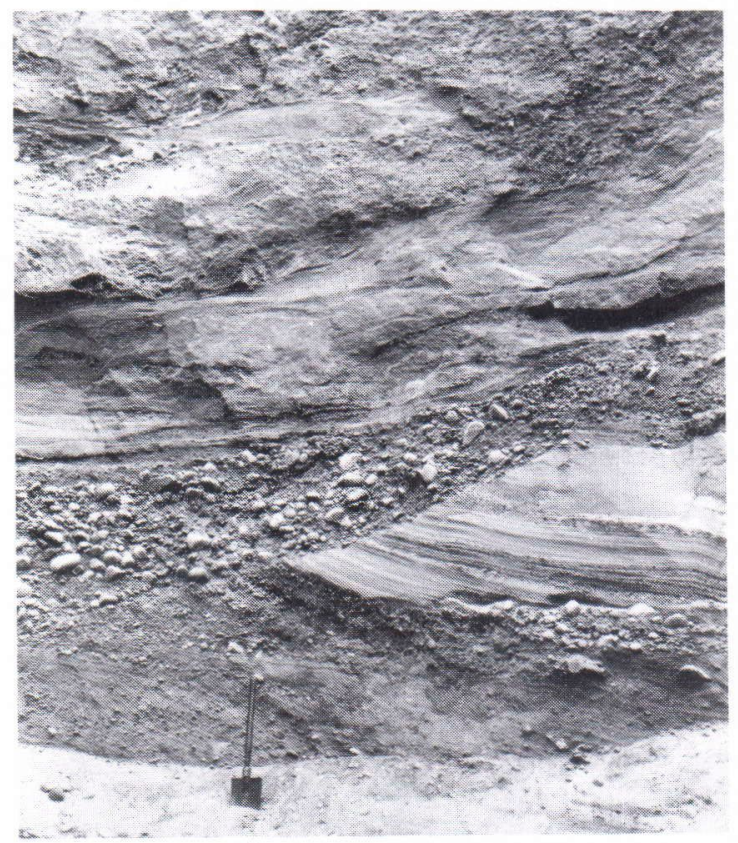

Fig. 10. Erosion - accumulation structure at Meltola. Photo 21. 7. 68 .
- glaciotectonic structures, folds, faults and discordances;

- secondary shore deposit structures, covering the formation (Figs. 12-13).

\section{Genesis}

Several theories have been presented for the genesis of the Salpausselkä formations in Finland (e.g. Sederholm 1889, 1910, Ramsay 1891, 1922, Leiviskä 1920, Sauramo 1931, 1958, Tanner 1933, Hyyppä 1951, 1966, Donner 1952, V. Okko 1957, M. Okko 1962, Virkkala 1963, 1979, Aartolahti 1968, Fogelberg 1970 and Glückert 1978, 1981). In general, the First Salpausselkä is made up of different types of deltas and other glaciogenic ridges. The material and structure of the formation vary considerably, being characterized by glaciofluvial structure dominated by a delta sediment sequence in the central and distal

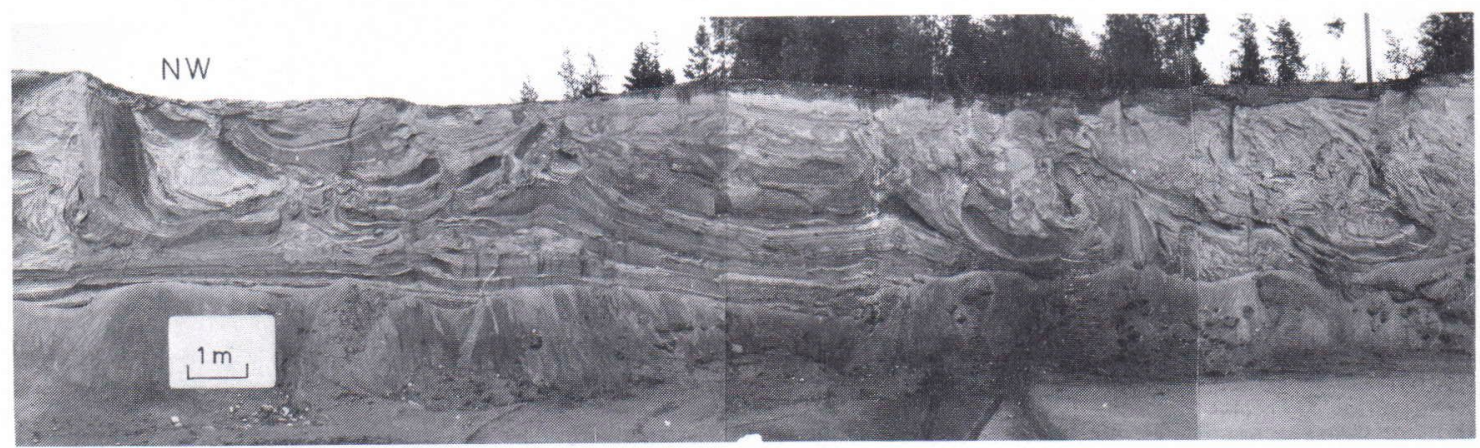

Fig. 11. Convolutions are common load cast phenomena in the proximal part of the First Salpausselkä (Nummela). As the upper coarse material (sand) sank in the plastic silt and formed synclinal convolution folds, the fine material rose to form anticlinal folds. Photo 26. 8. 80 . 

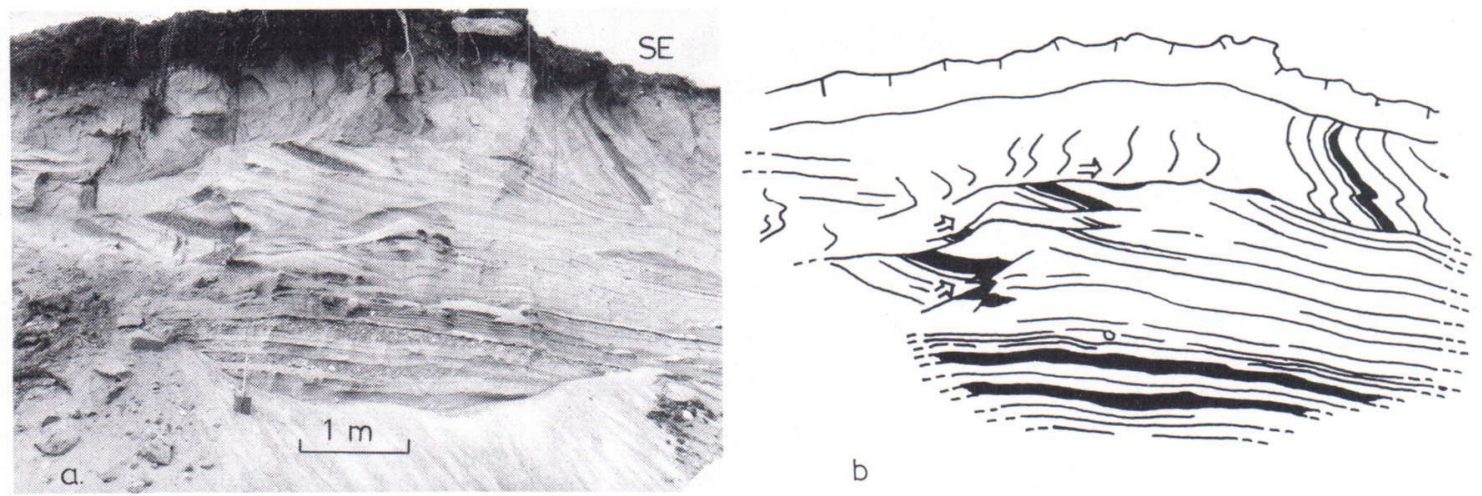

Fig. $12 \mathrm{~A}-\mathrm{B}$. The advancing glacier overrode the glaciofluvial strata, which became frozen at the bottom of the glacier and partially sheared into several faults. Gravel pit at Nummela. Photo 5. 9. 79.

parts of the formation and by complicated polygenetic structure in the proximal part.

The deposition of material in distinct formations did not begin and end at the same time in the Lohja area. The marginal deltas took longer to form than did the smaller ridges. Differences in the amount of material deposited and in the ice oscillation activity also influenced the size and morphology of the Salpausselkä (Figs. 14-15).
The genesis of the First Salpausselkä was studied in numerous sections. Conclusions regarding the conditions during the marginal and submarginal deposition, such as changes in water level and subaquatic sedimentation, variations in the intensity of glaciofluvial flow, and oscillations in the occasionally floating ice margin, were drawn from the material and structure.

Stratified layers of the oldest sediments were
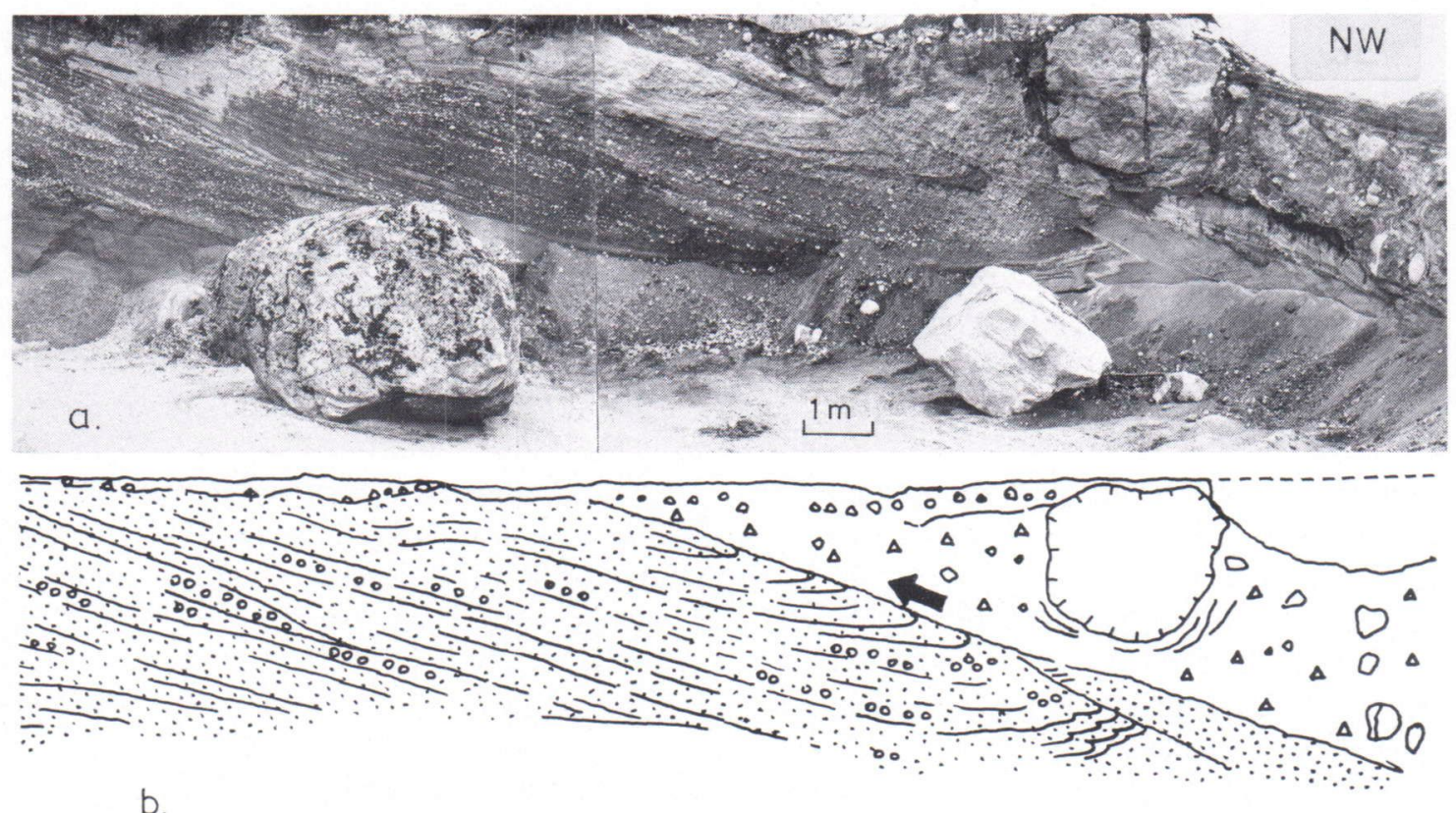

Fig. 13 A-B. A till layer pushed up onto a delta sequence by the advancing glacier, separated by a distinct shear plane. The topmost delta layers were in a frozen state and sheared into small faults. Gravel pit at Nummela. Photo 1968. 

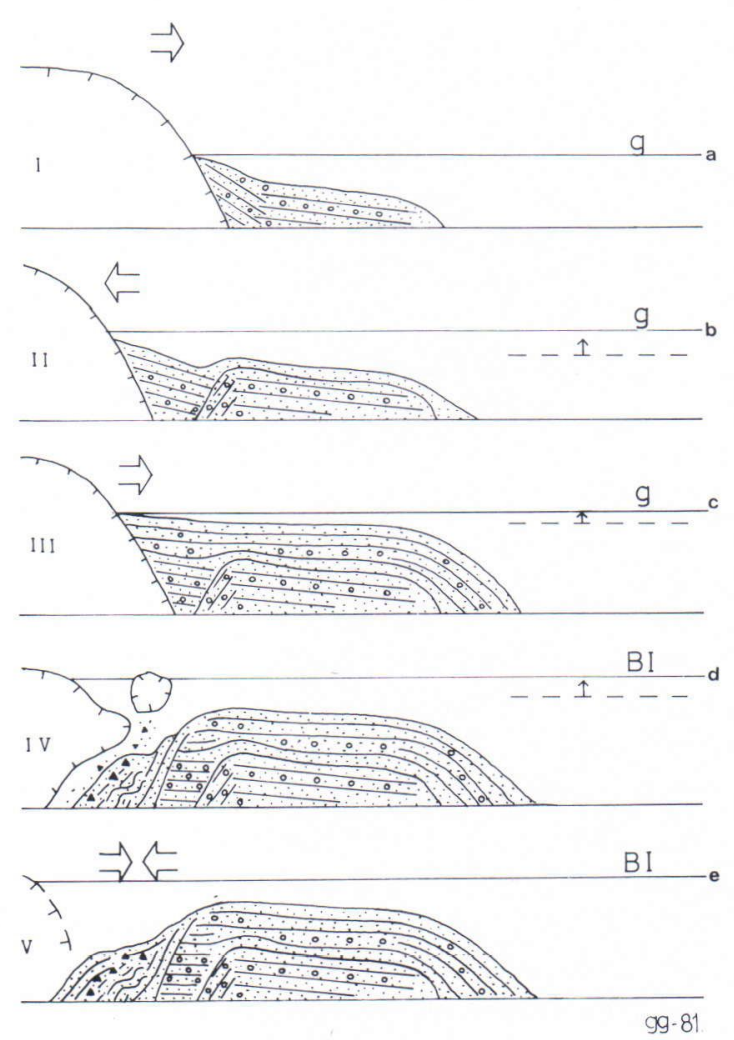

Fig. 14. Marginal deltas and narrow ridges were formed in several stages (1-5) (from Glückert 1981).

observed in some deep gravel pits. They indicate that the First Salpausselkä started to form partly under supra-aquatic conditions and partly during deposition of the first sediments in the shallow water of the ancient Baltic. The main part of the formation was deposited into the sea subaquatically when the water of the Baltic rose to its highest level, just before the beginning of the Baltic Ice Lake stage.

The material and structure of the proximal part of the formation indicate the complexity of the last phases of deposition. Before its final retreat, the ice margin oscillated several times, gliding on the slope and top of the formation, where the advancing glacier overrode and partly deformed the sedimented glaciogenic strata. At the same time

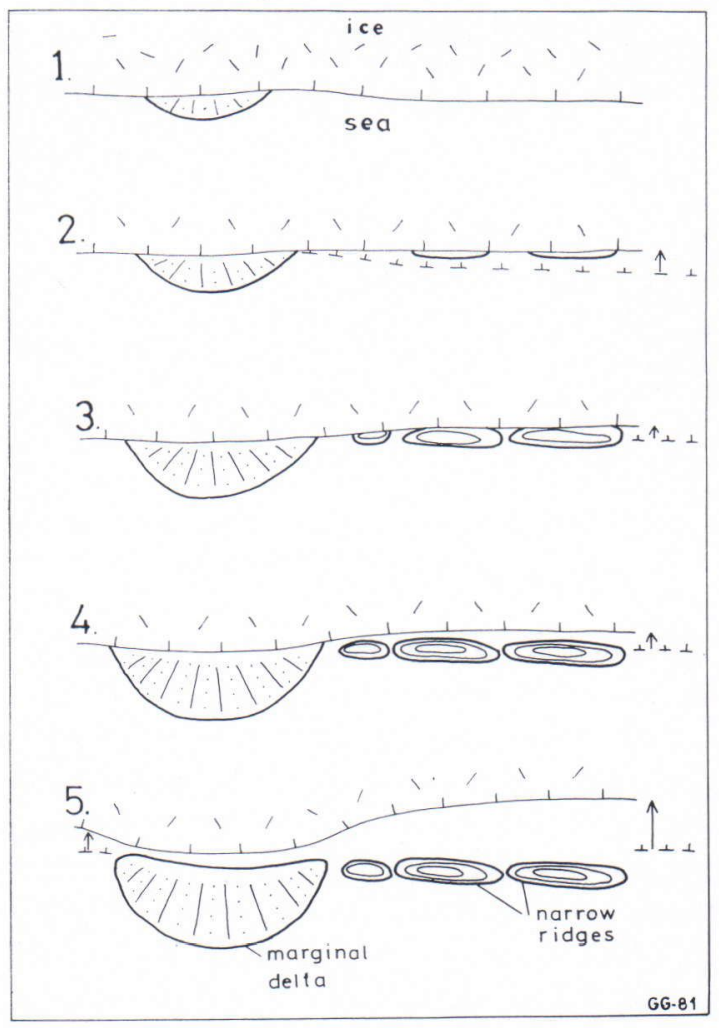

Fig. 15. Genesis of the Salpausselkä as the ice margin oscillated during the transgression of the water level from the $\mathrm{g}$ levels to B I, the highest position of the Baltic Ice Lake (from Glückert 1981).

subaquatic sedimentation continued, beds of coarse- and fine-grained stratified drift and meltout, partly waterlain till, depositing to form the youngest glaciogenic sequences of the formation. Further, the load of the sediments began to deform the primary structure in the proximal part. The last glaciogenic beds of the Salpausselkä to deposit are characterized by plastically deformed sand and silt layers as load casts (convolutions) and other consolidations structures (faults) (Figs. 11-13).

After a halt at the end of the Alleröd period the ice margin advanced to the position now marked by the First Salpausselkä. This happened at different times in different areas in southern Finland. Further, the retreat of the ice margin 
from the First Salpausselkä zone started unsynchronously after the formation of the Salpausselkä (Glückert 1977, 1979).

According to Sauramo $(1923,1940,1958)$, the First Salpausselkä substage lasted about 200 years, from 10,800 to $10,600 \mathrm{BP}$, but according to Niemelä (1971) from 11,250 to $11,000 \mathrm{BP}$.

The trend of deglaciation within the Salpausselkä belt is closely associated with the genesis of these ice-marginal formations. The general position and formation of the Salpausselkä seem to have been controlled primarily by climatic and topographic factors.

\section{Shore-level displacement}

As mentioned above the First Salpausselkä started to form partly under supra-aquatic con-

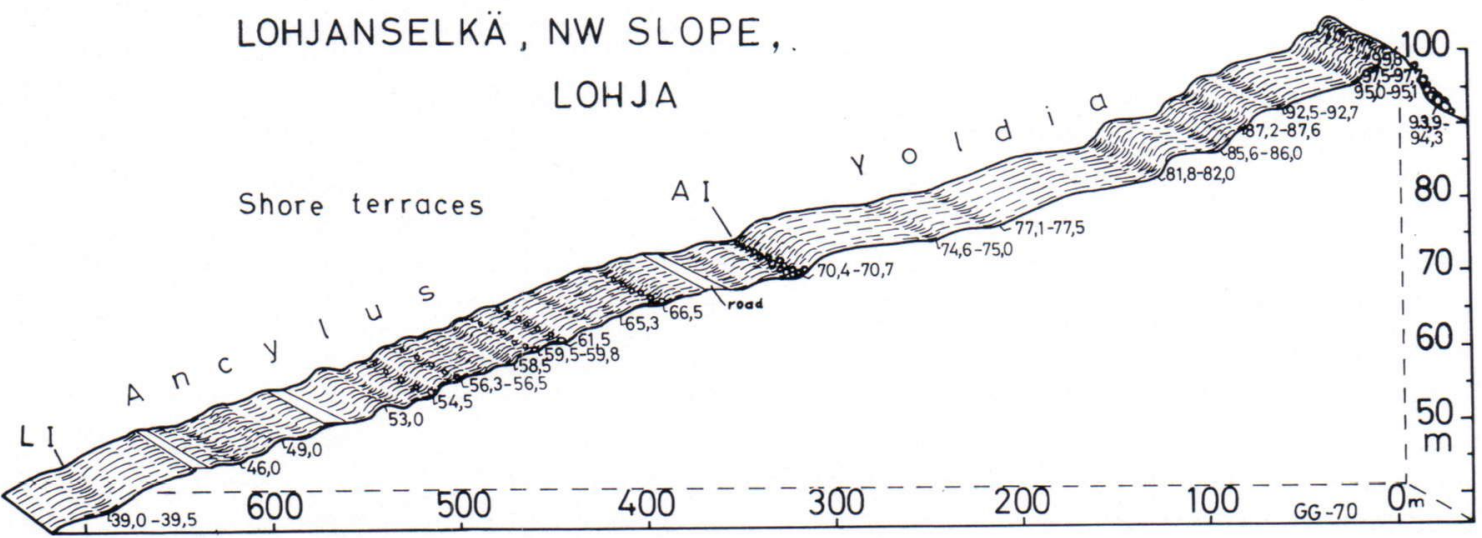

Fig. 16. Wave-cut cliffs and terraces are secondary erosion and accumulation formations on the slopes of the Salpausselkä (from Glückert 1970).

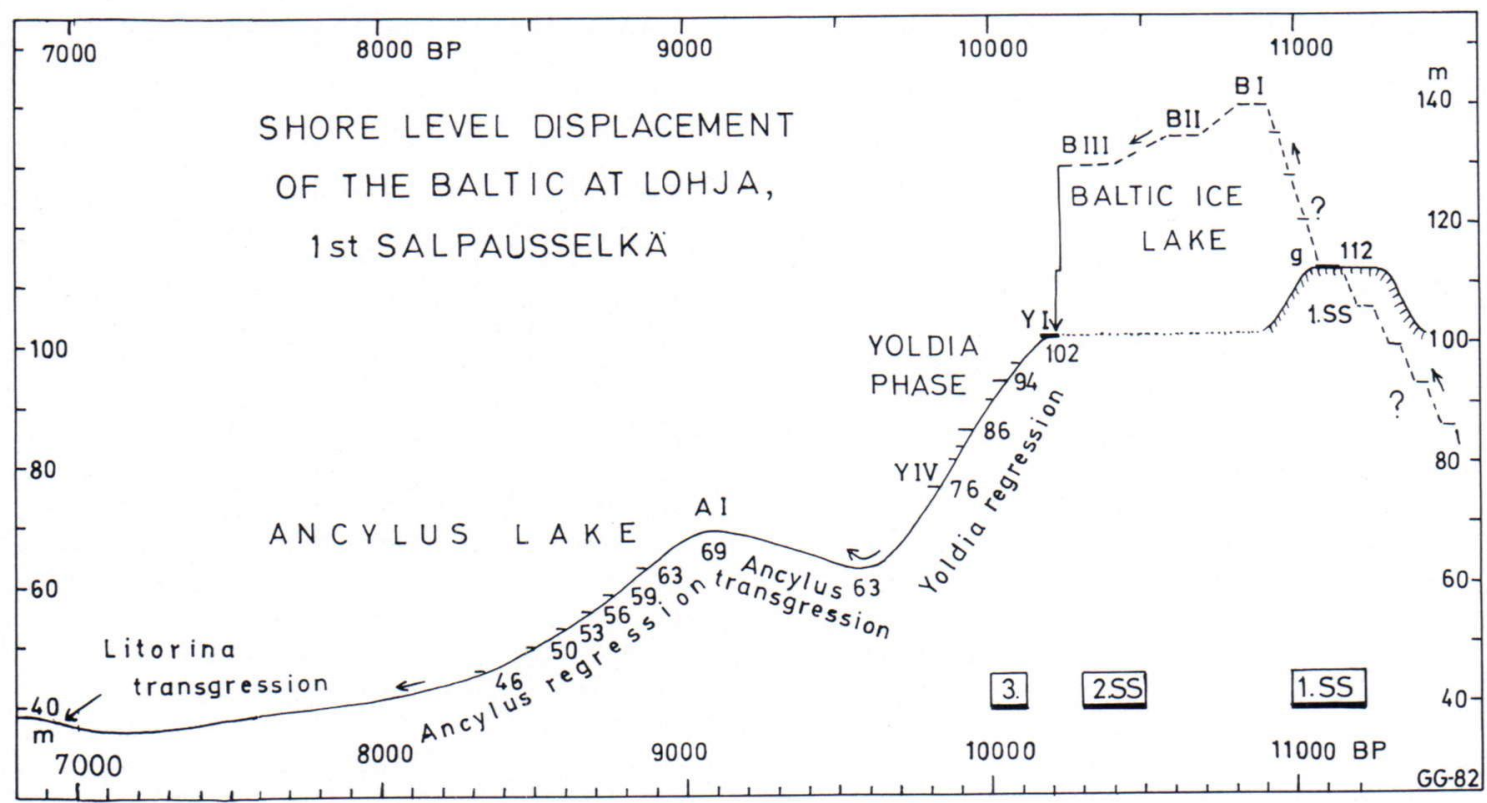

Fig. 17. Late and Post-Glacial shore-level displacement of the Baltic at Lohja. 
ditions when the level of the ancient Baltic was quite low. During the sedimentation of the Salpausselkä the water level rose gradually, and the bulk of the formation was deposited subaquatically in the sea. Sedimentation ended at 112-115 $\mathrm{m}$ a.s.l., shortly before the transgressive water level reached its highest point, B I, in the Baltic Ice Lake (about $140 \mathrm{~m}$ a.s.1.), some $30 \mathrm{~m}$ above the summit of the Salpausselkä (Sauramo 1958, Donner 1969, Glückert 1970, 1979, 1981) (Figs. 14, 15 and 17).

Before its final retreat, the glacier advanced to the proximal slope, and glided along the top of the formation, where it deposited drift rich in blocks (till). After the retreat this blocky material was deformed and washed by littoral forces of the sea, either when the water level was at 112 $\mathrm{m}$ and rose to B I or about 1000 years later, during the drainage of the Baltic Ice Lake into the Yoldia, when the water level sank below the summit of the formation. Today this blocky material forms ancient shores (boulder fields and bars) on the smooth tops of the marginal deltas at $112 \mathrm{~m}$ a.s.1. (Fig. $8 \mathrm{~A}$ ).

The smooth plateaux of the marginal deltas at $112 \mathrm{~m}$ at Lohja station, and at Nummela and Ojakkala (Fig. 2) mark one of the short-lived levels, called $g$ by Sauramo, during the transgression of the water level to B I at about 11,000 BP (Sauramo 1958, Glückert 1970, 1979, 1981). At the beginning of the Baltic Ice Lake stage the whole of the Salpausselkä was submerged, and the ice retreated NW in the Lohja area (Glückert 1970, 1979).

Followed by the rapid fall in the water level at the end of the Baltic Ice Lake from B III to Yoldia I at about 10,200 BP, the highest parts of the Salpausselkä, such as the marginal deltas, emerged from the sea. During this drainage of the Baltic to the ocean, wave action deformed and levelled the crests of the marginal deltas at $112 \mathrm{~m}$. Today these deltas can be regarded as secondary erosion plains (Fig. 17).

During the rapid Yoldia regression several prominent terraced shores were cut between 102 and $76 \mathrm{~m}$ a.s.l. in the slopes of the Salpausselkä. A clear Ancylus transgression observed at about 70 $\mathrm{m}$ a.s.l. in the Lohja area, took place between 9,700 and 9,000 BP (Glückert 1979, Glückert and Ristaniemi 1980, 1982). The next Ancylus regression left several well-marked shores between 63 and $46 \mathrm{~m}$ a.s.l. The youngest shoreline at Lohja is Litorina I at $39 \mathrm{~m}$ a.s.l., which also seems to be transgressive in this area (Figs. 16 and 17).

\section{References}

Aartolahti, Toive, 1968. Die Geomorphologie des Gebiets von Tammela, Südfinnland. Fennia 97, 7, 97 p.

-, 1972. On deglaciation in southern and western Finland. Fennia 114, 84 p.

Brenner, Thord \& Tanner, V., 1930. Södra Salpausselkäs byggnad i järnvägsskärningen för Lahti-Heinola banan. Fennia 52, 9, $16 \mathrm{p}$.

Donner, J. J., 1951. Pollen-analytical studies of Late-glacial deposits in Finland. Bull. Comm. géol. Finlande 154, $92 \mathrm{p}$.

—, 1952. Om Salpausselkä vid Hyvinge. Terra 64, 1, 1-5.

_, 1969. Land/Sea level changes in southern Finland during the formation of the Salpausselkä end moraines. Bull. Geol. Soc. Finland 41, 135-150.

Dreimanis, A., 1979. The problems of waterlain tills. In: Schlüchter, C. (ed.) Moraines and Varves. Rotterdam, 167-177.

Fogelberg, Paul, 1970. Geomorphology and deglaciation at the Second Salpausselkä between Vääksy and Vierumäki. Soc. Scient. Fennica, Comm. Physico-Math. 39, 90 p.

Glückert, Gunnar, 1969. Mannerjään kuljettamia kalkkikiviä Salpausselässä Lohjalla. Summary: Ice-transported limestone erratics in the material of First Salpausselkä in Lohja, south-western Finland. Geologi 21, 1, 8-9.

—, 1970. Vorzeitliche Uferentwicklung am Ersten Salpausselkä in Lohja, Südfinnland. Annales Univ. Turkuensis, Ser. A, III, 45, 116 p.

_, 1975. The Second Salpausselkä at Karkkila, southern Finland. Bull. Geol. Soc. Finland 47, 45-54.

-, 1977. On the Salpausselkä ice-marginal formations in 
southern Finland. Zeitschr. f. Geomorph. N. F. Suppl.Bd. 27, 78-88.

—, 1978. Das Deltakomplex von Kiikalannummi am 3. Salpausselkä in Südwestfinnland. Publ. Dept. Quaternary Geology, Univ. of Turku 35, 26 p.

—, 1979. Itämeren ja metsien historia Salpausselkävyöhykkeessä Uudenmaan länsiosassa. Summary: Shore-level displacement and the history of vegetation in the Salpausselkä belt, western Uusimaa, South Finland. Publ. Dept. Quaternary Geology, Univ. of Turku 39, 77 p.

—, 1981. Salpausselkien rakenteesta ja synnystä Lohjalla. Abstract: Structure and genesis of the 1st and 2nd Salpausselkä at Lohja, South Finland. Publ. Dept. Quaternary Geology, Univ. of Turku 45, 38 p.

- \& Ristaniemi, Olli, 1980. Ancylustransgressio Karjalohjalla Toisella Salpausselällä. Abstract: The Ancylus transgression in the area of Karjalohja, 2nd Salpausselkä, South Finland. Publ. Dept. Quaternary Geology, Univ. of Turku 41, $22 \mathrm{p}$.

-, 1982. The Ancylus transgression west of Helsinki, South Finland - a preliminary report. Ann. Acad. Sci. Fennicae A.III. 134, 99-110.

Hyyppä, Esa, 1951. Kuvia Salpausselän rakenteesta. Summary: On the structure of the First Salpausselkä. Geologi $3,2-3$.

—, 1966. I Salpausselän geologinen rakenne Lahden seudulla. Summary: On the structure of the First Salpausselkä at Lahti. Geologi 18, 6, 73-76.

Leiviskä, I., 1920. Der Salpausselkä. Fennia 41,3, 388 p.

—, 1923. Salpausselkä. Terra 35, 43-55.

—, 1927. Zwei Profile durch den Salpausselkä in Lohja. Fennia $47,11,12 \mathrm{p}$.

-, 1931. Zur Deutung des Profils durch den Salpausselkä bei Lahti. Bull. Comm. géol. Finlande 93, 12-14.

Metzger, A. A. Th., 1927. Ueber ein Profil durch die obersten Schichten des Salpausselkä zwischen Lohja und Keskilohja. Fennia 47, 7, 14 p.

Niemelä, Jouko 1971. Die Quartäre Stratigraphie von Tonablagerungen und der Rückgang des Inlandeises zwischen Helsinki und Hämeenlinna in Südfinnland. Bull. Geol. Surv. Finland 253, 79 p.

-, 1979 (ed.). Suomen sora- ja hiekkavarojen arviointiprojekti 1971-78. Summary: The gravel and sand resources of Finland: an inventory project 1971-78, $119 \mathrm{p}$.

Okko, Marjatta, 1962. On the development of First Salpausselkä, west of Lahti. Bull. Comm. géol. Finlande 202,
$162 \mathrm{p}$.

Okko, Veikko, 1957. The Second Salpausselkä at Jylisjärvi, east of Hämeenlinna. Fennia 81, 4, 46 p.

Punkari, Mikko, 1980. Vesimoreenit ja moreeninalaiset orgaaniset kerrostumat Pohjanlahden piirissä. Summary: Waterlain tills and submorainic organic sediments in the range of Gulf of Bothnia, Finland. Helsinki, 27 p.

Ramsay, Wilhelm, 1891. Ueber den Salpausselkä im östlichen Finnland. Fennia 4, 2, 8 p.

—, 1921. Salpausselkä såsom geografisk benämning. Referat: Salpausselkä als geographische Benennung. Fennia 42, 9, 12 p.

—, 1922. Randdeltan och strandlinjer i Salpausselkäbältet. Terra 34, 161-166.

Repo, Reino \& Tynni, Risto, 1967. Zur spät- und postglazialen Entwicklung im Ostteil des Ersten Salpausselkä. Bull. Comm. géol. Finlande 229, 133-159.

—, 1969. Morphologisch-stratigraphische Grundzüge des östlichen Salpausselkä-Gebiets. Bull. Geol. Soc. Finland 41, 203-229.

Sauramo, Matti, 1923. Studies on the Quaternary varve sediments in southern Finland. Bull. Comm. géol. Finlande $60,164 \mathrm{p}$.

—, 1931. Zur Frage des inneren Baues des Salpausselkä in Finland. Zeitschr. f. Gletscherk. XIX, 300-315.

—, 1940. Suomen luonnon kehitys jääkaudesta nykyaikaan. Porvoo \& Helsinki, 286 p.

—, 1958. Die Geschichte der Ostsee. Ann. Acad. Scient. Fennicae A. III. 51, 522 p.

Sederholm, J. J., 1889. Om istidens bildningar i det inre af Finland. Auszug: Über die Bildungen der Eiszeit im inneren Finnland. Fennia 1, 7, 52 p.

—, 1910. Suomen Kartasto (Atlas von Finnland). Karttalehti N:o 5, Fennoskandia.

Tanner, V., 1933. On the Nature of the Salpausselkä Ridges in Finland; Some old and new data. Fennia 58, 3, 36 p.

Wiik, F. J., 1876. Öfversikt af Finlands geologiska förhållanden. Akademisk afhandling. Helsingfors.

Virkkala, K., 1963. On ice-marginal features in southwestern Finland. Bull. Comm. géol. Finlande 210, 76 p.

-, 1964. Suomen geologinen kartta. Maaperäkartta. Geological map of Finland. Quaternary deposits. 1 : 100 000, N:o 2041, Lohja.

—, 1979. Om Salpausselkä-formationerna och andra randbildningar i södra Finland. Publ. Dept. Quaternary Geology, Univ. of Turku 38, 24 p. 